\title{
LETTER
}

\section{Raman spectroscopic study of olivine-group minerals}

\author{
Takashi MouRI and Masaki ENAMI \\ Department of Earth and Planetary Sciences, Nagoya University, \\ Chikusa-ku, Nagoya 464-8601, Japan
}

\begin{abstract}
Synthetic end-members $\mathrm{Mg}_{2} \mathrm{SiO}_{4}, \mathrm{Fe}_{2} \mathrm{SiO}_{4}, \mathrm{Mn}_{2} \mathrm{SiO}_{4}$, and $\mathrm{Co}_{2} \mathrm{SiO}_{4}$ and natural samples of forsterite-fayalite series, tephroite and monticellite, are investigated using Raman spectroscopy. The Raman spectra of the olivinegroup minerals have a characteristic set of two intense lines of the $\mathrm{Si}-\mathrm{O}$ asymmetric stretching band (wavenumber $\kappa_{1}$ ) and $\mathrm{Si}-\mathrm{O}$ symmetric stretching band $\left(\kappa_{2}\right)$. The $\kappa_{1}$ and $\kappa_{2}$ values of the $\mathrm{Mg}_{2} \mathrm{SiO}_{4}-\mathrm{Ca}(\mathrm{Mg}, \mathrm{Fe}) \mathrm{SiO}_{4}$ series, in which the M2 site is occupied by nontransition elements, vary from $847 \mathrm{~cm}^{-1}$ to $857 \mathrm{~cm}^{-1}$ and from $815 \mathrm{~cm}^{-1}$ to $825 \mathrm{~cm}^{-1}$, respectively, and their $\omega\left(=\kappa_{1}-\kappa_{2}\right)$ value is fairly constant around $32 \mathrm{~cm}^{-1}$. On the other hand, fayalite, tephroite, and other olivine-group minerals in which transition elements exist in the M2 site have a fairly constant $\kappa_{1}\left(836-839 \mathrm{~cm}^{-1}\right)$ value and variable $\kappa_{2}\left(808-819 \mathrm{~cm}^{-1}\right)$ and $\omega\left(20-32 \mathrm{~cm}^{-1}\right)$ values. The $\omega$ value of the forsterite-fayalite series systematically increases with $\mathrm{Mg} \#[=\mathrm{Mg} /(\mathrm{Mg}+\mathrm{Fe})]$ and is useful for determining their chemical compositions.
\end{abstract}

Keywords: Chemical composition, Solid solution, Olivine, Raman spectra

\section{INTRODUCTION}

Laser Raman microspectroscopy is a powerful tool for the detection of minute inclusions in optically transmissive host phases. Therefore, it can be used for the following purposes: (1) identification of high- and ultrahigh-pressure phases present in diamond, zircon, and other container phases (e.g., Sobolev and Shatsky, 1990; Sobolev et al., 1995; Tabata et al., 1998; Gillet et al., 2002), (2) estimation of chemical compositions of fluid inclusions (Burke, 2001), and (3) measurement of residual pressures retained by solid and fluid inclusions (Sobolev et al., 2000; Yamamoto et al., 2002; Enami et al., 2007).

The Raman spectra of solid solution phases systematically shift depending on their chemical compositions and pressure and temperature conditions. Thus, laser Raman microspectroscopy is also useful in the determination of the chemical compositions of minute phases in terrestrial and extraterrestrial materials and inclusions in diamond and other phases (e.g., Wang et al., 2004). The relationships between chemical compositions and Raman frequency shifts of the forsterite-fayalite series - the common constituent of mantle materials and meteorites - have been calibrated by Wang et al. (2004) and Kuebler et al. (2006), and a large inconsistency have been found between them.

doi:10.2465/jmps.071015

M. Enami, enami@eps.nagoya-u.ac.jp Corresponding author
The objectives of the present study are (1) to report the characteristics of the Raman spectra of olivine endmembers and (2) to newly calibrate the composition dependence of the Raman spectra of the forsterite-fayalite series.

\section{EXPERIMENTAL DETAILS}

Well-characterized synthetic single crystals of end-members $\mathrm{Mg}_{2} \mathrm{SiO}_{4}, \mathrm{Fe}_{2} \mathrm{SiO}_{4}, \mathrm{Mn}_{2} \mathrm{SiO}_{4}$, and $\mathrm{Co}_{2} \mathrm{SiO}_{4}$ (Sumino et al., 1977; Sumino, 1979) and natural samples of the forsterite-fayalite series, tephroite and monticellite, were used for Raman analyses. The chemical compositions of the natural olivine grains were determined using an electron-probe microanalyzer JEOL JXA-8800R (WDS + EDS). During the quantitative analyses, the accelerating voltage and specimen current of the Faraday cup were 15 $\mathrm{kV}$ and $12 \mathrm{nA}$, respectively (Table 1).

Raman spectra were obtained using a laser Raman microspectrophotometer Nicolet Almega XR (Thermo Fisher Scientific; gratings: 2400 lines $/ \mathrm{mm}$ ) equipped with a 532-nm Nd:YAG laser, a charge coupled device (CCD) detector (Andro Technology; $256 \times 1024$ pixels, cooled by a Peltier element), and an automated confocal microscope Olympus BX51. The objective lens was an Olympus Mplan-BD 100X lens $(\mathrm{NA}=0.9)$. The room temperature was maintained at $22 \pm 1{ }^{\circ} \mathrm{C}$. Details of analytical precision have been discussed by Enami et al. (2007). 
Table 1. Chemical compositions and localities of olivine for the Raman analyses

\begin{tabular}{|c|c|c|c|c|c|c|c|c|}
\hline Mineral & Sample No. & $\mathrm{Fe}$ & $\mathrm{Mn}$ & $\mathrm{Mg}$ & $\mathrm{Ca}$ & $\mathrm{Ni}$ & Host rock & Locality \\
\hline Fo-Fa & GO12Y06b & 0.127 & 0.002 & 1.866 & 0.000 & 0.006 & Peridotite & Sanbagawa belt/Besshi, Ehime \\
\hline Fo-Fa & FR05 & 0.136 & 0.007 & 1.850 & 0.000 & 0.008 & Dunite & Sanbagawa belt/Fujiwara, Ehime \\
\hline Fo-Fa & KS71091517 & 0.153 & 0.002 & 1.836 & 0.000 & 0.009 & Peridotite & Samburu, Kenya \\
\hline Fo-Fa & OL02-g1 & 0.157 & 0.002 & 1.833 & 0.000 & 0.008 & Peridotite & Unknown \\
\hline Fo-Fa & OL01-g2 & 0.161 & 0.000 & 1.837 & 0.000 & 0.003 & Peridotite & North Carolina, USA \\
\hline Fo-Fa & OL01-g3 & 0.187 & 0.000 & 1.811 & 0.000 & 0.003 & Peridotite & Unknown \\
\hline Fo-Fa & OL02-g3 & 0.203 & 0.003 & 1.785 & 0.002 & 0.007 & Peridotite & Unknown \\
\hline Fo-Fa & OL02-g2 & 0.204 & 0.003 & 1.785 & 0.001 & 0.007 & Peridotite & Unknown \\
\hline Fo-Fa & HG04A01b (C) & 0.300 & 0.005 & 1.688 & 0.003 & 0.004 & Basalt & Abu/Hagi, Yamaguchi \\
\hline Fo-Fa & HG04A01b (M) & 0.465 & 0.009 & 1.519 & 0.005 & 0.002 & Basalt & Abu/Hagi, Yamaguchi \\
\hline Fo-Fa & HG04A01b (R) & 0.568 & 0.013 & 1.410 & 0.006 & 0.003 & Basalt & Abu/Hagi, Yamaguchi \\
\hline Fo-Fa & HG04A02 & 0.704 & 0.010 & 1.275 & 0.007 & 0.005 & Andesite & Abu/Hagi, Yamaguchi \\
\hline Fo-Fa & TH83072308 & 0.793 & 0.011 & 1.195 & 0.001 & 0.000 & Ol-gabbro & Ryoke belt/Kajishima, Ehime \\
\hline Fo-Fa & GSJM17032 & 1.565 & 0.083 & 0.351 & 0.001 & 0.000 & Dacite & Hakone/Yugawara, Kanagawa \\
\hline Fo-Fa & $99-01$ & 1.635 & 0.046 & 0.306 & 0.012 & 0.000 & Dacite & Mt. Kenami/Abukuma, Fukushima \\
\hline Fo-Fa & $99-02$ & 1.657 & 0.047 & 0.282 & 0.013 & 0.000 & Dacite & Mt. Kenami/Abukuma, Fukushima \\
\hline Fo-Fa & OL01-g4 & 1.661 & 0.332 & 0.006 & 0.001 & 0.000 & Pegmatite & Kawamata, Fukushima \\
\hline $\mathrm{Fo}-\mathrm{Fa}$ & GSJM16253 & 1.759 & 0.137 & 0.101 & 0.004 & 0.000 & Pegmatite & Ugakei, Mie \\
\hline Fo-Fa & 7232915 (G01) & 1.770 & 0.073 & 0.128 & 0.028 & 0.000 & Trachyte & Oki-Dogo, Shimane \\
\hline Fo-Fa & 7232915 (G02) & 1.861 & 0.082 & 0.030 & 0.028 & 0.000 & Trachyte & Oki-Dogo, Shimane \\
\hline Fo-Fa & KO83090411 & 1.871 & 0.099 & 0.029 & 0.001 & 0.000 & Qtz-diorite & Ryoke belt/Anan, Nagano \\
\hline Monticellite & MX107 & 0.069 & 0.007 & 0.916 & 1.008 & 0.000 & Marble & California, USA \\
\hline Monticellite & TN01 & 0.302 & 0.067 & 0.627 & 1.004 & 0.000 & Marble & Kurio, Nagano \\
\hline Tephroite & MU406 & 0.021 & 1.696 & 0.261 & 0.023 & 0.000 & Mn-ore & Hokkejino, Kyoto \\
\hline Tephroite & $\mathrm{NC} 01$ & 0.030 & 1.856 & 0.109 & 0.005 & 0.000 & Mn-ore & Fujii mine/Mikata Fukui \\
\hline
\end{tabular}

Proportions of divalent cations are calculated as $\mathrm{Fe}+\mathrm{Mn}+\mathrm{Mg}+\mathrm{Ca}+\mathrm{Ni}=2.0$.

Abbreviations are: Fo-Fa, forsterite-fayalite series; C, core: M, mantle; R, rim; Ol-gabbro, olivine-gabbro; Qtz-diorite, quartz-diorite.

\section{SPECTROSCOPIC RESULT}

\section{Major end-members}

The factor group analysis predicts that the olivine structure with the Pnma symmetry has 36 Raman-active vibration modes: $11 A_{\mathrm{g}}+11 B_{1 \mathrm{~g}}+7 B_{2 \mathrm{~g}}+7 B_{3 \mathrm{~g}}$ (Chopelas, 1991). The Raman spectra of the olivine crystals have a characteristic set of two intense lines near $858-837 \mathrm{~cm}^{-1}\left[\kappa_{1}\right.$ : $\mathrm{Si}-\mathrm{O}$ asymmetric stretching band $\left.\mathrm{A}_{\mathrm{g}}\left(\mathrm{Si}_{-} \mathrm{O}\right)_{\mathrm{a}-\mathrm{str}}\right]$ and $825-808 \mathrm{~cm}^{-1}\left[\kappa_{2}\right.$ : $\mathrm{Si}-\mathrm{O}$ symmetric stretching band $\mathrm{A}_{\mathrm{g}}\left(\mathrm{Si}^{-}\right.$ O) $)_{\text {s-str }}$ (Fig. 1), and their positions are determined by curve fitting using a Voigt function. These frequency shifts are well consistent with those reported in the literature (e.g., Chopelas, 1991; Pilati et al., 1995; Lin, 2001). A study of the range of $\kappa_{1}$ and $\kappa_{2}$ values and their differences, $\omega\left(\kappa_{1}-\kappa_{2}\right)$, for differing types of olivine group minerals using both data reported in this contribution and values from the literature for $\mathrm{Ni}$-olivine and kirschsteinite reveals two distinct trends related to different compositional types. The first trend is represented by forsterite, monticellite, and kirschsteinite; absolute values of $\kappa_{1}$ $\left(858-847 \mathrm{~cm}^{-1}\right)$ and $\kappa_{2}\left(825-815 \mathrm{~cm}^{-1}\right)$ decrease in this order, but their $\omega$ values are approximately constant, around $32 \mathrm{~cm}^{-1}$. The second trend is shown by the Ni-olivine, fayalite, Co-olivine, and tephroite series that displays decreasing $\kappa_{2}$ values $\left(819-808 \mathrm{~cm}^{-1}\right)$ in this order, but approximately constant $\kappa_{1}$ values $\left(837-839 \mathrm{~cm}^{-1}\right)$, which results in an increase in the corresponding $\omega$ values. A significant difference between the two trends is the type of dominant element occupying the large octahedral M2 site: for all members of the second trend this element belongs to the transition element series, whereas none of the first series minerals contain significant amounts of transition elements. There have been extensive discussions on whether the two intense frequencies $\kappa_{1}$ and $\kappa_{2}$ depend on (1) the volume of the M1 site (Piriou and McMillan, 1983), (2) the distortion of the $\mathrm{SiO}_{4}$ tetrahedra in response to Ca substitution at the M2 site (Lam et al., 1990), and (3) the average mass (M) at the octahedral M1 and M2 sites, denoted by the parameter $\mathrm{M}^{-0.5}$ (Chopelas, 1991). However, it is clear from Figure 2 that the relationships 

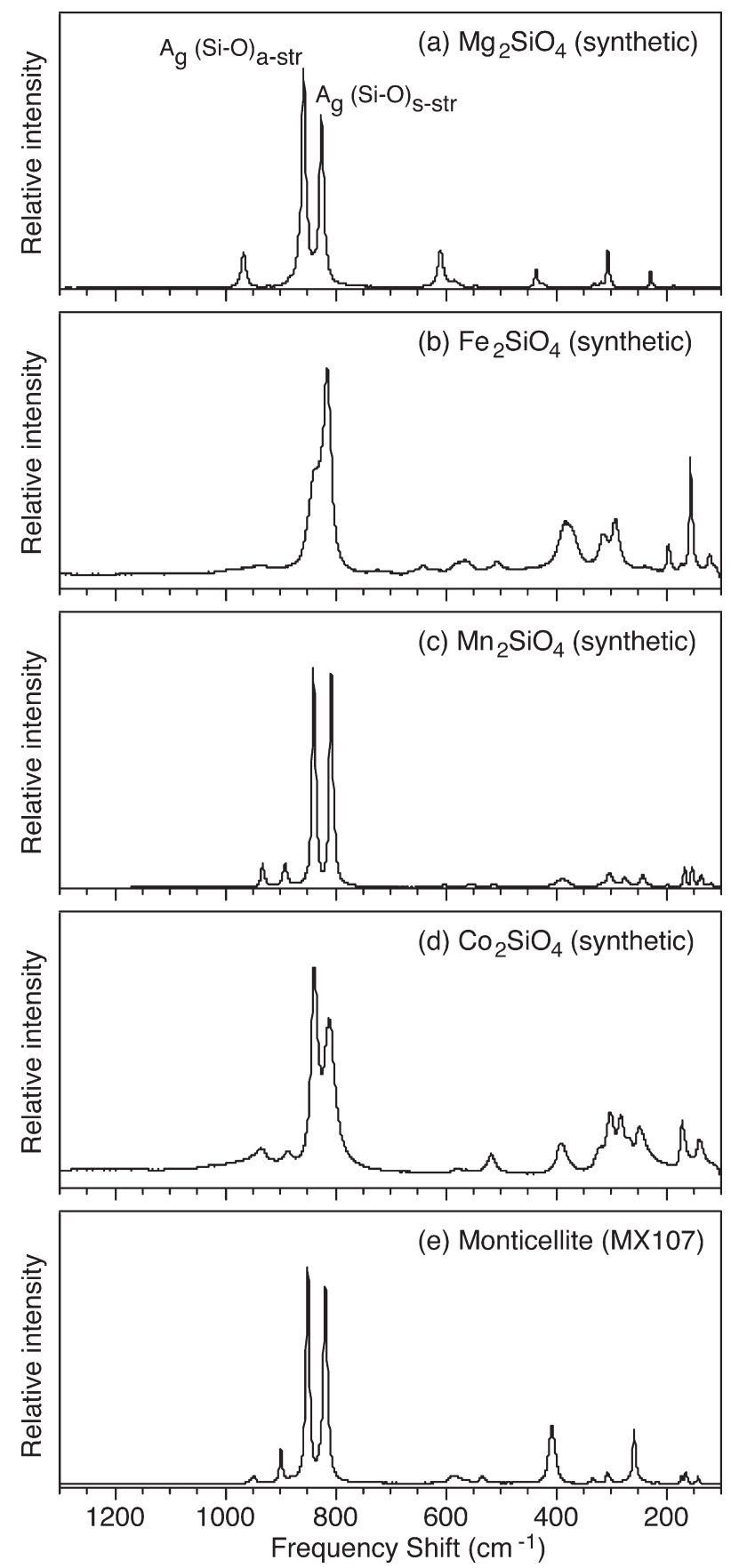

Figure 1. Ambient Raman spectra of olivine-group minerals.

between the frequency shifts and crystal chemistries of olivine are difficult to explain using only one of the proposed factors; for example, (1) the $\mathrm{CaMg}_{-1}$ and $\mathrm{CaFe}_{-1}$ substitutions at the M2 site affect the $\kappa_{1}, \kappa_{2}$, and $\omega$ values differently and (2) both the unit-cell volume and mass parameter $\mathrm{M}^{-0.5}$ do not correlate well with the variations in the frequency shifts. These facts imply that the frequency shifts depend on other factors and/or coupling effects of the proposed factors. The systematic differences in the frequency shifts between the forsterite/monticellite/

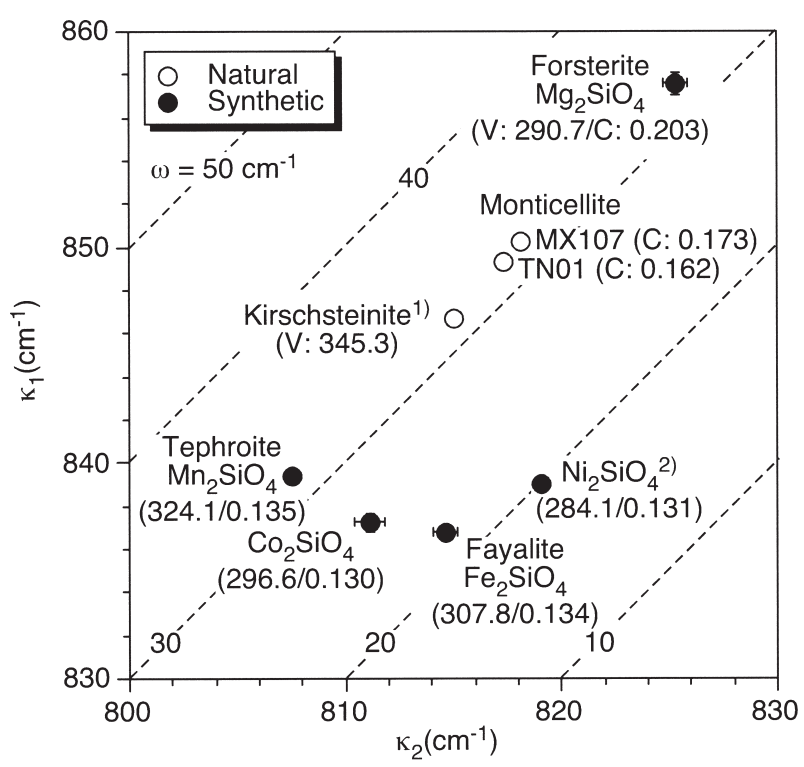

Figure 2. $\kappa_{1}, \kappa_{2}$, and $\omega$ variations of olivine-group minerals. The abbreviations used are as follows: $\mathrm{V}$ denotes the unit-cell volume and $\mathrm{C}$, the mass parameter $\left(\mathrm{M}^{-0.5}\right)$ proposed by Chopelas (1991). The Raman spectrum data are obtained from RRUFF database (http://rruff.info/) and Lin (2001). The unit-cell volume data are obtained from Sumino et al. (1976), Sumino (1979), Lin (2001), and RRUFF database.

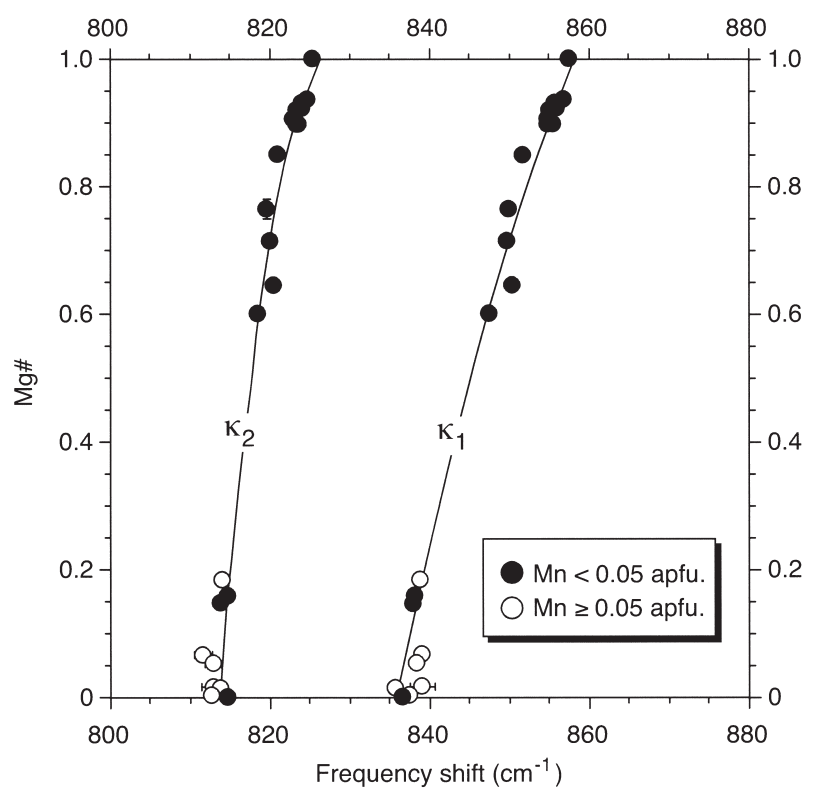

Figure 3. Relationships between peak positions of the strongest doublet $\left(\kappa_{1}\right.$ and $\kappa_{2}$ ) and $\mathrm{Mg} \#$ value of forsterite-fayalite series.

kirschsteinite series and the $\mathrm{Ni-olivine/fayalite/Co-oliv-}$ ine/tephroite series possibly suggest that the behavior of the transition and nontransition elements at the M2 site is the main factor responsible of controlling the Raman spectra of olivine. 


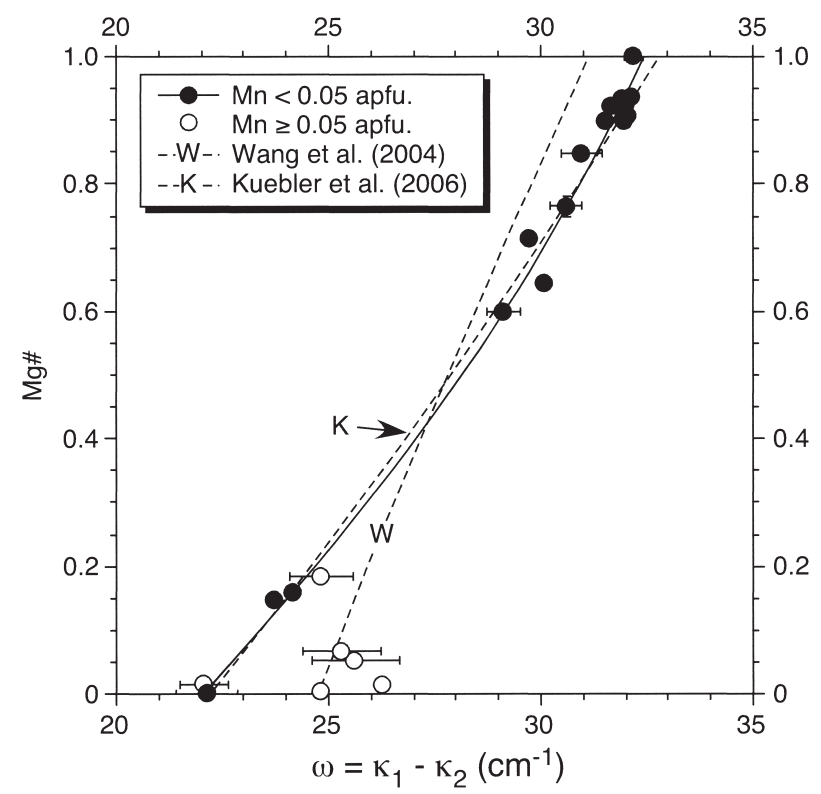

Figure 4. Relationships between $\omega$ and $\mathrm{Mg \#}$ values of forsteritefayalite series.

\section{Forsterite-fayalite series}

The relationships between the $\mathrm{Mg \#}\left[=\mathrm{Mg} /\left(\mathrm{Mg}+\mathrm{Fe}^{2+}\right)\right]$ value and the Raman frequency shifts of olivine have been discussed by Guyot et al. (1986), Wang et al. (2004), and Kuebler et al. (2006). The data show positive correlations between the peak positions of the strongest doublet $\left(\kappa_{1}\right.$ and $\kappa_{2}$ ) and the $\mathrm{Mg \#}$ value of $\mathrm{Mg}-\mathrm{Fe}$ olivine, although they exhibit slightly large scattering. We have recalibrated the relationships between the peak positions $\left(\kappa_{1}\right.$ and $\left.\kappa_{2}\right)$ and the Mg\# value of the olivine spectra (Fig. 3). The natural Fe-rich olivine generally contains considerable amounts of the tephroite component. The Mn content of Fe-rich olivine in this study is $\sim 0.3$ atoms per formula unit (apfu) for $\mathrm{O}=4$ (Table 1). Tephroite $\left(\kappa_{1}=839.3 \pm 0.1\right.$ $\mathrm{cm}^{-1}$ and $\left.\kappa_{2}=807.5 \pm 0.1 \mathrm{~cm}^{-1}\right)$ has a higher $\kappa_{1}$ value and a lower $\kappa_{2}$ value than fayalite $\left(\kappa_{1}=836.8 \pm 0.5 \mathrm{~cm}^{-1}\right.$ and $\kappa_{2}=814.7 \pm 0.3 \mathrm{~cm}^{-1}$ ), and its incorporation into Fe-rich olivine increases the $\kappa_{1}$ value and decreases the $\kappa_{2}$ value. Our new calibrations of the $\kappa_{1}-\mathrm{Mg} \#$ and $\kappa_{2}-\mathrm{Mg} \#$ relationships obtained using the $\mathrm{Mn}$-poor $\mathrm{Mg}-\mathrm{Fe}$ olivine $(\mathrm{Mn}<$ $0.05 \mathrm{apfu})$ are as follows:

$$
\begin{aligned}
& \mathrm{Mg} \#=-610.65+1.3981 \kappa_{1}-0.00079869 \kappa_{1}^{2} \\
& \quad\left(\text { correlation coefficient: } \mathrm{r}^{2}=0.99\right) \\
& \mathrm{Mg} \#=-3715.8+8.9889 \kappa_{2}-0.0054348 \kappa_{2}^{2} \\
& \quad\left(\mathrm{r}^{2}=0.96\right) .
\end{aligned}
$$

It would be preferable to use the difference between the $\omega$ values in order to avoid systematic errors in the measurements of individual $\kappa_{\mathrm{i}}$ values and propose a new calibration technique for the frequency shift and Mg\# value of olivine (Fig. 4). The $\omega$ value systematically increases with the $\mathrm{Mg} \#$ value, except for limited Fe-rich olivines with $\mathrm{Mg \#}<0.2$. The incorporation of the tephroite $(\omega=$ $31.8 \mathrm{~cm}^{-1}$ ) component into Fe-rich olivine (fayalite: 22.1 $\mathrm{cm}^{-1}$ ) increases the $\omega$ value. Thus, the scattered $\omega$ values of Fe-rich olivine can be primarily attributed to the $\mathrm{MnFe}_{-1}$ substitution. The calibrated $\omega-\mathrm{Mg} \#$ relationship is as follows:

$$
\begin{aligned}
\mathrm{Mg} \# & =-0.17744-0.050049 \omega+0.0026479 \omega^{2} \\
\left(\mathrm{r}^{2}\right. & =0.99) .
\end{aligned}
$$

Our calibration is well consistent with the $\omega^{-\mathrm{Mg} \#}$ relationship calculated from the dataset of Kuebler et al. (2006). The measurement precision of $\omega$ is $0.4 \mathrm{~cm}^{-1}$ or less in the conventional Raman analysis and results in an accuracy of 0.03-0.04 in the determination of $\mathrm{Mg} \#$.

\section{Application and discussion}

Raman spectroscopy is advantageous for the estimation of chemical compositions of solid solution phases present in optically transmissive host phases such as diamond. The inclusions, however, retain compressive or tensile stresses (e.g., Sobolev et al., 2000; Enami et al., 2007), and the measured frequency shifts of solid solution phases integrate the information on their chemical compositions and internal stress. The values of the pressure derivatives $\left(\mathrm{d} \kappa_{\mathrm{i}}\right)$ $\mathrm{dP})$ of the $\kappa_{1}$ and $\kappa_{2}$ values of forsterite are $2.85-3.27 \mathrm{~cm}^{-1}$ $\mathrm{GPa}^{-1}$ and $3.07-3.12 \mathrm{~cm}^{-1} \mathrm{GPa}^{-1}$, respectively (Chopelas, 1990; Wang et al., 1993). On the other hand, the values of the pressure dependence of $\omega$ are in the range of $-0.22-0.15 \mathrm{~cm}^{-1} \mathrm{GPa}^{-1}$, which are one order of magnitude less than those of $\kappa_{1}$ and $\kappa_{2}$ values.

Izraeli et al. (1999) have estimated the residual pressure retained in the olivine inclusions in diamond to be 0.13-0.65 GPa based on their frequency shift $\left(\kappa_{1}\right)$ relative to a free olivine grain $\left(0.4-2.0 \mathrm{~cm}^{-1}\right)$ and calculated the mantle residual pressures to be $4.4-5.2 \mathrm{GPa}$ at $1200{ }^{\circ} \mathrm{C}$. In their calculation, the olivine composition is assumed to be independent of $\mathrm{Mg} \#=0.93$. However, our calibration indicates that the measured frequency shifts $\left(\kappa_{1}: 0.4-2.0\right.$ $\mathrm{cm}^{-1}$ ) can be induced by the $\mathrm{Mg} \#$ changes of $0.01-0.06$, thereby eliminating the effect of the residual pressure. Although the olivine inclusions in diamond are fairly uniform in composition, the variations in their $\mathrm{Mg \#}$ values of up to 0.04 (e.g., Tsai et al., 1979; Sobolev et al., 1997) are significant for the olivine Raman barometer. Thus, the postulated constant olivine composition $(\mathrm{Mg} \#=0.93$; Izraeli et al., 1999) probably has significant effects on the 
calculation of the residual and source pressures. The residual pressure of an olivine inclusion should be carefully estimated using combinations of $\kappa_{1} / \kappa_{2}$ values that are sensitive to pressure and composition and $\omega$ value that are sensitive to composition.

\section{ACKNOWLEDGMENTS}

The authors thank K. Syuto, S. Nakano, Y. Banno, and T. Niwa for lending the olivine samples. They are also grateful to two anonymous reviewers for their constructive comments. The study was partially supported by grants from the Japan Society for the Promotion of Science (ME: Nos. 18340172 and 19654080).

\section{REFERENCES}

Burke, E.A.J. (2001) Raman microspectrometry of fluid inclusions. Lithos, 55, 139-158.

Chopelas, A. (1990) Thermal properties of forsterite at mantle pressure derived from vibrational spectroscopy. Physics and Chemistry of Minerals, 17, 149-156.

Chopelas, A. (1991) Single crystal Raman spectra of forsterite, fayalite, and monticellite. American Mineralogist, 76, 1101-1109.

Enami, M., Nishiyama, T. and Mouri, T. (2007) Laser Raman microspectrometry of metamorphic quartz: A simple method for comparison of metamorphic pressures. American Mineralogist, 92, 1303-1315.

Gillet, P., Sautter, V., Harris, J., Reynard, B., Harte, B. and Kunz, M. (2002) Raman spectroscopic study of garnet inclusions in diamonds from the mantle transition zone. American Mineralogist, 87, 312-317.

Guyot, F., Boyer, H., Madon, M., Velde, B. and Poirier, J.P. (1986) Comparison of the Raman microprobe spectra of $(\mathrm{Mg}, \mathrm{Fe})_{2}$ $\mathrm{SiO}_{4}$ and $\mathrm{Mg}_{2} \mathrm{GeO}_{4}$ with olivine and spinel structures. Physics and Chemistry of Minerals, 13, 91-95.

Izraeli, E.S., Harris, J.W. and Navon, O. (1999) Raman barometry of diamond formation. Earth and Planetary Science Letters, 173, 351-360.

Kuebler, K.E., Jolliff, B.L., Wang, A. and Haskin, L.A. (2006) Extracting olivine ( $\mathrm{Fo}-\mathrm{Fa}$ ) compositions from Raman spectral peak positions. Geochimica et Cosmochimica Acta, 70, 6201-6222.

Lam, P.K., Yu, R., Lee, M.W. and Sharma, S.K. (1990) Sructural distortions and vabrational modes in $\mathrm{Mg}_{2} \mathrm{SiO}_{4}$. American Mineralogist, 75, 109-119.

Lin, C.C. (2001) High-pressure Raman spectroscopic study of $\mathrm{Co}^{-}$and $\mathrm{Ni}^{-}$olivines. Physics and Chemistry of Minerals, 28, 249-257.

Pilati, T., Demartin, F. and Gramaccioli, C.M. (1995) Thermal parameters for minerals of the olivine group: their implication of vibrational spectra, thermodynamic functions and transferable force fields. Acta Crystallographica, B51, 721-733.

Piriou, B. and McMillan, P. (1983) The high-frequency vibrational spectra of vitreous and crystalline orthosilicates. American Mineralogist, 68, 426-443.

Sobolev, N.V. and Shatsky, V.S. (1990) Diamond inclusions in garnets from metamorphic rocks; a new environment for diamond formation. Nature, 343, 742-746.

Sobolev, N.V., Shatsky, V.S., Vavilov, M.A. and Goryaynov, S.V. (1995) Zircon in high-pressure metamorphic rocks in folded regions as a unique container of inclusions of diamond, coesite, and coexisting minerals. Transactions of the Russian Academy of Sciences. Earth Science Sections, 336, 79-85.

Sobolev, N.V., Kaminsky, F.V., Griffin, W.L., Yefimova, E.S., Win, T.T., Ryan, C.G. and Botkunov, A.I. (1997) Mineral inclusions in diamonds from the Sputnik kimberlite pipe, Yakutia. Lithos, 39, 135-157.

Sobolev, N.V., Fursenko, B.A., Goryainov, S.V., Shu, J., Hemley, R.J., Mao, H.K. and Boyd, F.R. (2000) Fossilized high pressure from the Earth's deep interior: the coesite-in-diamond barometer. Proceedings of National Academy of Sciences, USA, 97, 11875-11879.

Sumino, Y. (1979) The elastic constants of $\mathrm{Mn}_{2} \mathrm{SiO}_{4}, \mathrm{Fe}_{2} \mathrm{SiO}_{4}$ and $\mathrm{Co}_{2} \mathrm{SiO}_{4}$, and the elastic properties of olivine group minerals at high temperature. Journal of Physics of Earth, 27, 209-238.

Sumino, Y., Ohno, I., Goto, T. and Kumazawa, M. (1976) Measurement of elastic constants and internal frictions on singlecrystal $\mathrm{MgO}$ by rectangular parallelepiped resonance. Journal of Physics of Earth, 24, 263-273.

Sumino, Y., Nishizawa, O., Goto, T., Ohno, I. and Ozima, M. (1977) Temperature variation of elastic constants of singlecrystal forsterite between -190 degrees and $400{ }^{\circ} \mathrm{C}$. Journal of Physics of Earth, 25, 377-392.

Tabata, H., Maruyama, S. and Shi, Z. (1998) Metamorphic zoning and thermal structure of the Dabie ultrahigh-pressure-highpressure terrane, central China. The Island Arc, 7, 142-158.

Tsai, H.M., Meyer, H.O.A., Moreau, J. and Milledge, H.J. (1979) Mineral inclusions in diamond: Premir, Jagersfontein and finsh kimberlite, South Africa, and Williamson mine, Tanzania. In Kimberlites, Diatremes, and Diamonds: Their Geology, Petrology, and Geochemistry (Boyd, F.R. and Meyer, H.O.A. Eds.). 1, American Geophysical Union, Washington, D.C., 16-26.

Wang, A., Kuebler, K.E., Jolliff, B.L. and Haskin, L.A. (2004) Mineralogy of a Martian meteorite as determined by Raman spectroscopy. Journal of Raman Spectroscopy, 35, 504-514.

Wang, S.Y., Sharma, S.K. and Cooney, T.F. (1993) Micro-Raman and infrared spectral study of forsterite under high pressure. American Mineralogist, 78, 469-476.

Yamamoto, J., Kagi, H., Kaneoka, I., Lai, Y., Prikhod'ko, V.S. and Arai, S. (2002) Fossil pressures of fluid inclusions in mantle xenoliths exhibiting rheology of mantle minerals; implications for the geobarometry of mantle minerals using microRaman spectroscopy. Earth and Planetary Science Letters, 198, 511-519.

Manuscript received October 15, 2007

Manuscript accepted December 4, 2007

Manuscript handled by Eiji Ohtani 